\title{
Analysis of Fraud Pentagon Theory to Detecting Fraudulent Financial Reporting using F-Score Model in State-Owned Companies Indonesia
}

\author{
TARMIZI ACHMAD \\ Faculty of Economics and Business, Diponegoro University, Semarang, INDONESIA \\ DIAN INDRIANA HAPSARI \\ IMANG DAPIT PAMUNGKAS \\ Faculty of Economics and Business, Dian Nuswantoro University, Semarang, INDONESIA
}

\begin{abstract}
This study aims to analyze the effect of the fraud pentagon theory consisting of external pressure, effective monitoring, rationalization, capability, and arrogance on fraudulent financial reporting. This study uses the F-score model to see the potential for fraudulent financial reporting. The data used in this study are secondary data from the company's annual reports. The population of this research is state-owned companies listed on the IDX (Indonesia Stock Exchange) during 2015-2019. The sampling technique used purposive sampling so that the sample obtained is 180 samples. The analysis technique used is logistic regression analysis with S.P.S.S. versions 20.0. The findings show that external pressure and rationalization have a significant effect on fraudulent financial reporting. Meanwhile, effective monitoring, capability, and arrogance have no considerable impact on fraudulent financial reporting. The results of this study indicate the occurrence of fraudulent financial reporting in state-owned companies listed on the IDX if the related state-owned companies experience external pressure and have rationalizations to commit fraud.
\end{abstract}

Key-Words: - Fraudulent Financial Reporting, Fraud Pentagon Theory, F-scores Model.

Received: June 5, 2021. Revised: November 21, 2021. Accepted: January 8, 2022. Published: January 10, 2022.

\section{Introduction}

Financial reports are essential tools for companies in communicating financial information to investors or creditors [1]. [2] classify fraud into three categories, namely, asset misappropriation, corruption, and fraudulent financial reporting. A survey conducted in 2020 found that of the three types of fraud, fraudulent financial reporting was one of the lowest, the Percentage was $10 \%$, but suffered the most loss of the two other fraud cases valued at $\$ 954,000$ [2]. Then this fact can prove that this annual account is the most destructive type of fraud. In addition, Indonesia was also elected for the first time with 16 countries with fraud cases in the Asia Pacific Region. Fraud cases usually occur more internally than in external companies, the corporate environment [3].

Management deliberately carries out fraudulent financial reporting with a specific purpose [4];[5]. The Fraud Pentagon Theory is an evolution of the Fraud Triangle Theory by adding two new elements. The elements that are added to this theory are competence and arrogance [6]. [7] found that fraudulent financial reporting poses a significant risk to companies and can affect long-term success. [8] stated that fraud is common in Indonesia, from the government to banking to corporations. The recent case in Indonesia involved a sizeable stateowned company is Garuda Indonesia. The results of an audit by the Financial Services Authority (O.J.K.) showed there were debt fund violations. However, reported in the financial reports of Garuda Indonesia in 2018 were recorded as income. Therefore deviated from Article 69 of Law No. 8 of 1995 on the Capital Market and the Ordinance of Bapepam and L.K. No. VIII.G.7 on the presentation and disclosure of ex issuers and public companies [9].

Developed various analyses to detect indications of fraudulent financial reporting, the study used the F-Score model, a model developed by [10]. The FScore model is the sum of two variables: provision quality and financial performance [11]. One of the factors influencing fraudulent financial reporting is external pressure. According to [12], the most common example of pressure is borrowing additional debt or external funding sources to keep the company competitive. [8], [13]-[15] found that external pressure significantly affects fraudulent financial reporting. However, [16] found that external pressure did not substantially impact fraudulent financial reporting.

Fraud occurs due to inadequate supervision, which creates an opportunity to commit fraud [17]. 
[18] found that effective monitoring had a significant positive effect on fraudulent financial reporting. [19] found that effective monitoring had a significant negative impact on fraudulent financial reporting. [13], [17] found that effective monitoring did not significantly affect fraudulent financial reporting. [12] found rationalization has a significant positive effect on fraudulent financial reporting. [20][21] found that rationalization did not significantly impact fraudulent financial reporting.

Capability is a person's ability or power to commit fraud within a company [22]. The position of executives in a company can be a determining factor in fraud. [23] found that the capability had a significant negative impact on fraudulent financial reporting, while [13] found that the capability did not substantially affect fraudulent financial reporting. [24] note that arrogance is a characteristic of a lack of conscience as an attitude of superiority or arrogance in someone who believes that they cannot personally have internal control. [8] found that arrogance has a significant positive effect on fraudulent financial reporting, while [25] [20] found that arrogance did not substantially impact fraudulent financial reporting.

\section{Literature Review}

\subsection{Fraud Pentagon Theory}

The Fraud Pentagon Theory is known as the Crowe's Fraud Pentagon. The elements added to this theory are competence and arrogance. [8] Arrogance is the greed and attitude of superiority of people who believe that company procedures or policies do not affect them. Such a person completely ignored the consequences imposed on the victim. Arrogance and competence play a central role in determining whether employees currently have something they need to carry out fraud. [6] argues that the fraud triangle theory needs to be adapted to the current era when technology is rapidly advancing. They then propose two additional elements, capability, and arrogance, referred to as Crowe's Fraud Pentagon. The Fraud Pentagon Theory evolves the Fraud Triangle Theory by adding two new elements: capability and arrogance.

\subsection{Hypotheses Development}

\section{External Pressure on Fraudulent Financial Reporting}

Under external pressure, a company may find a higher risk of material misstatement due to fraud. [18] also state that any element or combination of several factors can encourage someone to commit fraud. Fraud has two keywords; the first is willful fraud, meaning the act is being carried out consciously, and the perpetrator is aware of the fraud. The second keyword is a fraud, which affects the manipulated object. Research results from [1], [26]-[28] found that external pressure affects fraudulent financial reporting. This suggests that fraudulent financial reporting is due, among other things, to an excessive outside force, as explained by [13]. These studies have strengthened the truth of the Fraud Pentagon Theory.

H1: External pressure affects fraudulent financial reporting.

\subsection{Effective Monitoring on Fraudulent Financial Reporting}

Fraud stems from inadequate supervision that enables a person to commit fraud [29]. Due to the ineffectiveness of oversight, management believes that its performance is out of control, which leads management to seek to optimize its profits. Effective oversight is the condition of a company when it does not have an adequate oversight unit to monitor company performance [30]. Fraud is the result of inadequate monitoring that a manager or agent may have the capability to engage in deviant behavior. Good surveillance can reduce fraudulent practices. It is believed that the independent Board of Commissioners can promote the effectiveness of corporate oversight, whose job it is to ensure the implementation of corporate strategy. [5], [20] found effective monitoring affects fraudulent financial reporting.

$\mathrm{H} 2$ : Effective monitoring affects fraudulent financial reporting.

\subsection{Rationalization of Fraudulent Financial Reporting}

[18] say that rationalization is the third pillar of the fraud triangle and is challenging to measure. [29] state that fraud is begun based on an attitude, character, or set of ethical values that enable the act to be carried out. People in an urgent environment force them to rationalize the fraud they have committed. Rationalization arises as a person seeks to justify activities that contain copy [31]. [5], [32], [33] found that rationalization affects fraudulent financial reporting. This means that cheating begins based on an attitude, character, or set of ethical values that allows it to be made possible. Described action [34]. These studies have strengthened the truth of the Pentagon fraud theory. This theory explains that rationalization, replaced by overall boundaries, can affect fraudulent financial reporting. 
H3: Rationalization affects fraudulent financial reporting.

\subsection{Capability of Fraudulent Financial Reporting}

According to [35], capability is the ability or power that a person has to commit fraud within a company. On the contrary, the change in the board of directors could eliminate the old board of directors who already knew about the company's fraud [36]. The various traits described by [37] relate to the skill element in the actions of the cheating agent, namely the skill, such as position/function, brain, selfconfidence/ego, obsessive-compulsive skills, effective lying, and immunity to stress. [22], [38] found that capability affects fraudulent financial reporting. This shows that fraud occurs due to abuse of leadership positions in the company, as stated by [26]. These studies have strengthened the truth of the fraud pentagon theory.

H4: Capability affects fraudulent financial reporting.

\subsection{Arrogance of Fraudulent Financial Reporting}

According to [6], due to the level of organization, C.E.O. will do everything to maintain his position and position in a company. [13] stated that arrogance caused by the frequency of C.E.O. image appearances influences fraudulent financial reporting. Changes in the board of directors/board of directors can also lead to periods of stress, impacting the development of fraud opportunities. This is because the new board of directors or directors does not have full knowledge of the company, which leads to ineffective performance and thus opens up opportunities for fraud. [12], [23], [24], [30] found that arrogance has an impact on fraudulent financial reporting.

H5: Arrogance affects fraudulent financial reporting.

\section{Method}

The population in this study are state-owned companies in Indonesia that are listed on the Indonesia Stock Exchange (IDX) from www.IDX.co.id. The research sample was determined by purposive sampling. The sample used has two criteria, namely state-owned companies, which are listed consecutively in the IDX in the period 2015-2019, and state-owned companies in the IDX with complete data on all required variables in the period 2015-2019. So, with the research period, obtained 36 state-owned companies five years, namely 2015-2019, or in other words, there were 180 samples in this study. This study uses secondary data from financial reports, annual reports, and summaries of the financial performance of state-owned companies listed on the IDX from 2015 to 2019 . The quantitative data analysis in this study used logistic regression analysis using S.P.S.S. version 20.0. The following is a logistic regression equation used in this study.

\section{Ln Fraud $=$ 1-Fraud \\ $\beta_{0}+\beta_{1} \mathrm{LEV}, \quad \beta_{2} \mathrm{IND}, \quad \beta_{3} \mathrm{TACC}, \quad \beta_{4} \mathrm{DCHANGE}$, $\beta_{5}$ CEOPIC}

\section{Information:}
Fraud
$=$ Fraudulent Financial Reporting
Ln
$=$ Natural Logarithm
$\beta_{0}$
$=$ Constant regression coefficient

$\beta_{1}, \beta_{2}, \beta_{3}, \beta_{4}, \beta_{5}=$ Regression coefficient for each variable

$\begin{array}{ll}\text { LEV } \quad= & \text { Comparison of Total Debt to Total } \\ & \text { Assets } \\ \text { IND } \quad & \begin{array}{l}\text { Percentage of number of } \\ \text { Independent Audit Committees }\end{array} \\ \text { T.A.C.C. }= & \text { Total accruals } \\ \text { D.C.H.A.N.G.E. }=\text { occurrence of changes in the }\end{array}$ composition of the board of directors

C.E.O.P.I.C. $=$ Total C.E.O. photos plastered in the annual report

Table 1. Operational Definition of Variables

\begin{tabular}{|c|c|c|}
\hline Variables & Measurement & Source \\
\hline \multirow[t]{2}{*}{$\begin{array}{l}\text { Pressure } \\
\text { (X1) }\end{array}$} & $\begin{array}{l}\text { External Pressure (LEV) } \\
=\end{array}$ & [39] \\
\hline & $\begin{array}{l}\text { Total Liability/ Total } \\
\text { Asset }\end{array}$ & \\
\hline $\begin{array}{l}\text { Opportunity } \\
\text { (X2) }\end{array}$ & $\begin{array}{l}\text { Effective monitoring = } \\
\text { Number of independent } \\
\text { members of the } \\
\text { examination board } \\
\text { total number of the } \\
\text { examination board }\end{array}$ & [17] \\
\hline $\begin{array}{l}\text { Rationalizat } \\
\text { ion (X3) }\end{array}$ & $\begin{array}{l}\text { Total Accrual Ratio = } \\
\text { Total Accrual (Net } \\
\text { Income-Cashflow } \\
\text { Operation/Total Assets }\end{array}$ & [40] \\
\hline $\begin{array}{l}\text { Capability } \\
\text { (X4) }\end{array}$ & $\begin{array}{l}\text { Capability is measured } \\
\text { by a dummy variable } \\
\text { where if there is a } \\
\text { change in the company's } \\
\text { directors during the } \\
2015-2019 \text { period, it is } \\
\text { coded } 1 \text {. If there is no }\end{array}$ & [13] \\
\hline
\end{tabular}




\begin{tabular}{|c|c|}
\hline & $\begin{array}{l}\text { change in the company's } \\
\text { directors during the } \\
2015-2019 \text { period, it is } \\
\text { coded } 0 .\end{array}$ \\
\hline $\begin{array}{l}\text { Arrogance } \\
\text { (X5) }\end{array}$ & $\begin{array}{l}\text { The indicator of this } \\
\text { arrogance factor is } \\
\text { denoted by C.O.P.I.C., } \\
\text { which is the number of } \\
\text { photos of the C.E.O. } \\
\text { displayed in a company } \\
\text { annual report. }\end{array}$ \\
\hline $\begin{array}{l}\text { Fraudulent } \\
\text { Financial } \\
\text { Reporting }\end{array}$ & $\begin{array}{l}\text { The calculation uses F- } \\
\text { scores. }\end{array}$ \\
\hline Source: Ex & $\begin{array}{l}\text { xtracted from various journals, } 2021 \\
\text { Table 2. F-Scores Formula }\end{array}$ \\
\hline \multicolumn{2}{|c|}{$\begin{array}{l}\text { F-Scores = Accrual Quality + Financial } \\
\text { Performances } \\
\text { Accrual Quality is calculated using RSST Accrual. } \\
\text { RSST Accrual }=(\Delta \mathrm{WC}+\Delta \mathrm{NCO}+\Delta \mathrm{FIN}) \\
\text { Averages Total Assets }\end{array}$} \\
\hline \multicolumn{2}{|c|}{ Information: } \\
\hline \multicolumn{2}{|c|}{$\begin{array}{l}\text { WC }=\text { Current Assets - Current Liability } \\
\mathrm{NCO} \quad=\text { (Total Assets - Current Assets - } \\
\text { Investment and Advances) - (Total Liabilities- } \\
\text { Current Liabilities - Long Term Debt) }\end{array}$} \\
\hline & $=$ Total Investment - Total Liabilities \\
\hline \multicolumn{2}{|l|}{$\begin{array}{l}\text { ATS } \\
\text { Assets) / } 2\end{array}$} \\
\hline \multicolumn{2}{|l|}{ Information: } \\
\hline & $=V$ \\
\hline $\mathrm{NCO}$ & $=$ Non-Current Operat \\
\hline & \\
\hline & \\
\hline
\end{tabular}

Financial Performances $=$

Change in Receivables + Change in Inventories + Change in Cash Sales + Change in Earnings.

Information:

Change in Receivables $=\Delta$ Receivables / Average Total Assets

Change in Inventories $=\Delta$ Inventories $/$ Average Total Assets

Change in Earnings $=($ Earnings $(\mathrm{t}) /$ Average Total Assets (t)) - (Earnings ( $\mathrm{t}-1) /$ Average Total Assets (t-1))

\section{Results And Discussion}

\subsection{Research Data}

This study was conducted period 2015-2019 on state-owned companies that went public in Indonesia and reported their financial reports on the Indonesian Stock Exchange. There are 38 State-
Owned Enterprises listed or listed on the IDX in the 2015-2019 period. There are two state-owned companies on the IDX with incomplete data for the 2015-2019 period. The sample consisted of 36 stateowned companies on the IDX and with complete data from 2015-2019. So, that with the time series data method (2015-2019), the number of observations $(\mathrm{n})=180$.

Table 3. Determination of Research Samples

\begin{tabular}{llc}
\hline No & \multicolumn{1}{c}{ Information } & $\begin{array}{c}\text { Amount } \\
\text { Company }\end{array}$ \\
\hline 1 & $\begin{array}{l}\text { State-Owned Companies that are } \\
\text { listed or listed on the IDX in } \\
\text { succession in the 2015-2019 } \\
\text { period. }\end{array}$ \\
\hline 2 & $\begin{array}{l}\text { State-Owned } \\
\text { companies on the IDX with } \\
\text { incomplete data for the 2015- }\end{array}$ \\
2019 period. & \\
\hline & Research Samples & 36 \\
\hline & $\begin{array}{l}\text { Amount of Research Data } \\
\text { (36 x 5 years) }\end{array}$ \\
\hline Source: Processed & 180 \\
\hline
\end{tabular}

Source: Processed secondary data, 2021

\subsection{Descriptive Statistics}

This study analyzed descriptive statistical data from the research variables. The minimum value accompanies the explanation of the data, maximum value, mean, variance, and standard deviation. Descriptive statistics of research data can be seen in Table 4.

Table 4. Descriptive Statistics of Research Data for the Period of 2015-2019

\begin{tabular}{|c|c|c|c|c|c|}
\hline Variable & $\mathrm{N}$ & Min & Max & Mean & SD \\
\hline $\begin{array}{l}\text { External } \\
\text { Prescure }\end{array}$ & 180 & .10 & 1.69 & .4554 & $\begin{array}{l}.22 \\
245\end{array}$ \\
\hline $\begin{array}{c}\text { Effective } \\
\text { Monitoring }\end{array}$ & 180 & .25 & .88 & .4443 & $\begin{array}{l}.10 \\
812\end{array}$ \\
\hline $\begin{array}{l}\text { Rationalizat } \\
\text { ion }\end{array}$ & 180 & -.60 & 1.63 & .0006 & $\begin{array}{l}0.4 \\
769\end{array}$ \\
\hline Capability & 180 & .00 & 1.00 & .2438 & $\begin{array}{c}.42 \\
289\end{array}$ \\
\hline Arrogance & 180 & 1.00 & 8.00 & 3.3783 & $\begin{array}{l}2.8 \\
330 \\
\end{array}$ \\
\hline $\begin{array}{c}\text { Fraudulent } \\
\text { Financial } \\
\text { Reporting }\end{array}$ & 180 & .00 & 1.00 & .0461 & $\begin{array}{l}.20 \\
06\end{array}$ \\
\hline $\begin{array}{c}\text { Valid N } \\
\text { (listwise) }\end{array}$ & 180 & & & & \\
\hline
\end{tabular}

Source: Processed secondary data, 2021 
Based on Table 4. the average value for external pressure (leverage) is 0.45 . The lowest external pressure value was 0.10 , and the highest external pressure value was 1.69 . The mean value of the monitoring effectiveness was 0.44 . The lowest monitoring effectiveness value was 0.25 , and the highest practical monitoring value was 0.88 . The average for rationalization is 0.0006 . The lowest rationalization value is -0.60 , and the highest rationalization value is 1.63 . The average skill score was 0.0006 . The lowest capability value of 0 indicates that the company's directors have not changed, and the highest skill value of 1 indicates that the company's directors have changed. The mean value of the Arrogance variables using the size of the number of C.E.O. photos displayed in the State-Owned Companies annual reports on the IDX from 2015 to 2019 is 3.33. The lowest arrogance variable number is one, and the arrogance variable number is 8 . The average value of fraudulent financial reporting using the F-score measurement is measured by the dummy variable of 0.04 . The lowest number of fraudulent deals 0 indicates that the company is not engaged in close fraud with a value of $\mathrm{f}<1.00$, and the highest number of fraudulent sales is 1, which suggests an f-score> 1.00. These results are in the classification Table 5. as follows to see.

From classification table 5 . it can be analyzed that the $2 \times 2$ contingency table that should occur or is also known as the frequency of expectations is based on empirical data of the dependent variable. Companies determine the number of samples with the category of the dependent variable is fraudulent financial reporting (code 1) consists of 5 dates. Meanwhile, 175 companies were the companies that did not commit fraudulent financial reporting (code $0)$.

Table 5. Classification Test Result

\begin{tabular}{|c|c|c|c|}
\hline & Predicted & & \\
\hline \multirow[t]{2}{*}{ Observed } & $\begin{array}{c}\text { Fraudulent } \\
\text { Financial } \\
\text { Reporting }\end{array}$ & & $\begin{array}{c}\text { Percentage } \\
\text { Correct }\end{array}$ \\
\hline & .00 & 1.00 & 100.0 \\
\hline Step 0 & & & \\
\hline Fraudulent & & 0 & .0 \\
\hline Financial & & 0 & \\
\hline Reporting & & & \\
\hline .00 & & & \\
\hline 1.00 & & & \\
\hline Overall & & & 97.15 \\
\hline
\end{tabular}

a. Constant is included in model

b. The cut value is 0.500

\subsection{Determination Coefficient}

The coefficient of determination essentially measures the extent to which the model's capability to deal with the independent variables, namely external pressure, monitoring effectiveness, rationalization, capability, and arrogance, along with the explanation of the variation of the dependent variable (Fraudulent Financial Reporting) with the output indicator as follows.

Table 6. Result of the Coefficient of Determination

\begin{tabular}{cccc}
\hline Step & $\begin{array}{c}\mathbf{- 2} \text { Log } \\
\text { like hood }\end{array}$ & $\begin{array}{c}\text { Cox \& } \\
\text { Snell R } \\
\text { Square }\end{array}$ & $\begin{array}{c}\text { Nagelkerke } \\
\text { R Square }\end{array}$ \\
\hline 1 & 29.179 & 0.980 & .335 \\
\hline
\end{tabular}

a. Estimation terminated at iteration number 8 because parameter estimates changed by less than .001

The test results show that the coefficient of determination for the Cox and Snell R-squared tests is 0.098 and for the Negelkerke R-squared, 0.335, which means that the variability of the dependent variable can explain the variability of the independent variable is $33.5 \%$.

\subsection{Result}

In the Hosmer and Lemeshow test, a significance level of $0.057>$ significance level was obtained $(5 \%$ $=0.05)$. The research data model for explaining the research variables was classified as suitable or sound and feasible. In addition, the model feasibility test can be seen from the results of the omnibus test. Chi-square value of $12.391>$ chi-square table on D.F. (number of independent variables 5) which is 11.07 or with a significance of $0.030(<0.05)$. Discards H0, indicating that adding independent variables can have a natural effect on the model, or in other words, declaring the model fit. The coefficient of determination for the Cox and Snell R-squared test is 0.098 , and the Negelkerke Rsquared test is 0.335 , which means that the dependent variable's variability can be explained by the variability of the independent variable, $33,5 \%$. The logistics model in this study can be described as follows.

$$
\begin{aligned}
& \operatorname{Ln} \frac{\text { Fraud }}{1-\text { Fraud }}=3.646-6,396 \text { X1 }-7,191 \text { X2 }+5,591 \\
& \text { X3 - 0,312 X4 - 0,255 X5 }
\end{aligned}
$$

The regression equation explains the following:

- A constant value of 3.646 means that the company's fraudulent financial reporting 
increases by 3.646 when all independent variables are considered steady or consistent.

- The external pressure regression coefficient (X1) is -6.396. This means that when external pressures increase by $1 \%$, fraudulent financial reporting decreases by 6,396 while the other independent variables are considered constant.

- The regression coefficient of effective Monitoring (X2) of $-7,191$. This means that when the effective Monitoring increases by $1 \%$, fraudulent financial reporting decreases by 7,191, while the other independent variables are considered constant.

- Rationalization regression coefficient (X3) of 5,591. Suppose rationalization has increased by $1 \%$ while the other independent variables are considered constant, fraudulent financial reporting increases by 5,591 .

- Skill regression coefficient (X4) of -0.312. If the capability has increased by $1 \%$ while the other independent variables are considered constant, the fraudulent financial reporting will decrease by 0.312 .

- The regression coefficient of Arrogance (X5) is 0.255 . If arrogance has increased by $1 \%$ while the other independent variables are considered constant, fraudulent financial reporting decreases by 0.255 .

\subsection{Hypothesis Test}

Hypothesis testing uses a logistic regression test performed simultaneously on all variables: external pressure, monitoring effectiveness, rationalization, capability, and arrogance in fraudulent financial reporting. The test results are as follows.

Table 7 Multivariate Test Results

\begin{tabular}{clccc}
\hline $\begin{array}{c}\text { Hy } \\
\text { po } \\
\text { Th } \\
\text { esis }\end{array}$ & Variable & $\begin{array}{c}\text { Coeffi } \\
\text { cient } \\
\text { Value }\end{array}$ & $\begin{array}{c}\text { P- } \\
\text { Value }\end{array}$ & Result \\
\hline $\mathrm{H} 1$ & $\mathrm{X} 1 \longrightarrow \mathrm{Y}$ & -6.396 & 0.029 & Accepted \\
\hline $\mathrm{H} 2$ & $\mathrm{X} 2 \longrightarrow$ & -7.191 & 0.474 & Rejected \\
& $\mathrm{Y}$ & & & \\
\hline $\mathrm{H} 3$ & $\mathrm{X} 3 \longrightarrow$ & 5.591 & 0.032 & Accepted \\
& $\mathrm{Y}$ & & & \\
\hline $\mathrm{H} 4$ & $\mathrm{X} 4 \longrightarrow$ & -0.312 & 0.805 & Rejected \\
& $\mathrm{Y}$ & & & \\
\hline $\mathrm{H} 5$ & $\mathrm{X} 5 \longrightarrow$ & -0.255 & 0.287 & Rejected \\
& $\mathrm{Y}$ & & & \\
\hline
\end{tabular}

\subsubsection{External Pressure on Fraudulent Financial Reporting}

The results showed that external pressure (X1) had a significant and negative effect on fraudulent financial reporting $(\mathrm{Y})$. The value of the regression coefficient is $-6,396$, and the probability value $(\mathrm{P})$ for the external pressure variable (X1) for fraudulent financial reporting (Y) is $0.029<$ level of significance $(5 \%=0.05)$.

[42] explain that this is likely because external parties, namely creditors, can monitor the progress of the company's debt cycle to reduce the possibility of fraudulent financial reporting. In addition, the creditors will consider various factors that will influence whether to apply for a loan. Of course, creditors will approve loan applications to companies that already have a credible and good image and are not authorized by the O.J.K. Hence, these various factors prevent companies from tampering with financial statements despite having financial risks with high leverage ratios.

The results of this study are in agreement with research by [1], [12], [26], [28]. They found that external pressure had an impact on fraudulent financial reporting. This suggests that fraudulent financial reporting is due, among other things, to an excessive outside force, as explained by [13]. These studies have strengthened the truth of the fraud pentagon theory.

\subsubsection{Effective Monitoring on Fraudulent Financial Reporting}

The results showed no significant impact between the supervision effectiveness (X2) variable on fraudulent financial reporting (Y). The regression coefficient value is -7.191 , and the probability value (P) for the variable Supervision Effectiveness (X2) for fraudulent financial reporting $(\mathrm{Y})$ is 0.474 .> The significance level $(5 \%=0.05)$ [17] stated that this could be due to the hiring of the Board of Commissioners in the company just to meet the regulatory requirements, namely O.J.K. No. 33/PJOK.04/2014. Therefore, the appointment of the independent committee of commissioners is only for the fulfillment of good corporate governance, so the role and function of the independent committee of commissioners in overseeing the company are not maximal. The results of this study are the results of the survey [16]. [5], [32], [33] found that effective monitoring does not affect fraudulent financial reporting. 


\subsubsection{Rationalization of Fraudulent Financial Reporting}

The results showed a significant and positive influence between the rationalization variable (X3) on fraudulent financial reporting $(\mathrm{Y})$. The regression coefficient value is 5,591 . The probability $(\mathrm{P})$ for the rationalization (X3) for fraudulent financial reporting $(\mathrm{Y})$ is 0.032 . According to [43], this is due to the delimitation concept. This means that management can manipulate income by capturing when the transaction occurs even though the money has not been paid out or received. The results of this study are in agreement with the research carried out by [15], [18], [44], who found that rationalization affects fraudulent financial reporting. This means that fraud is committed based on an attitude, character, or set of ethical values that make it possible to carry out the actions described by [34]. These studies have strengthened the truth of the fraud pentagon theory. This theory explains that rationalization, replaced by overall boundaries, can affect fraudulent financial reporting.

\subsubsection{Capability on Fraudulent Financial Reporting}

The results showed no significant influence between the capability variable (X4) on fraudulent financial reporting $(\mathrm{Y})$. The regression coefficient value is 0.312 , and the probability $(\mathrm{P})$ for the capability variable $(\mathrm{X} 4)$ for fraudulent financial reporting $(\mathrm{Y})$ is 0.805 . $>$ The significance level $(5 \%=0.05$. [5] stated that this could happen because made a change of directors. After all, the previous director failed to perform his duties and responsibilities. According to [37], it can improve corporate performance by hiring more competent directors than previous directors, which impacts better business performance. The tendency towards fraudulent financial reporting is very low. This study's results agree with research by [22], [26], who found the capability did not affect fraudulent financial reporting.

\subsubsection{Arrogance of Fraudulent Financial Reporting}

The results showed no significant influence between the arrogance variable (X5) on fraudulent financial reporting $(\mathrm{Y})$. The regression coefficient value is 0.255 , and the probability $(\mathrm{P})$ for the arrogance variable (X5) of fraudulent financial reporting $(\mathrm{Y})$ is 0.287 . $>$ The significance level $(5 \%=0.05)$ indicates that between none, the arrogance variable (X5) versus fraudulent financial reporting $(\mathrm{Y})$ has a significant impact. [32] note that this happens because the photo of the C.E.O. shown in the company's annual report can be a form of transparency about who is responsible for the company's activities and a form of leadership involvement and responsibility for each action of the company. The results of this study are in agreement with research by [26], [45], [46] found that arrogance did not affect fraudulent financial reporting.

\section{Conclusions}

This investigation explains that if there is external pressure and rationalization, it will affect fraudulent financial reporting. However, effective oversight, skill, and arrogance do not materially affect fraudulent financial reporting. The higher the external pressure on the company, the lower the fraudulent financial reporting of the company. This is because external parties, namely creditors, can monitor the course of the company's debt cycle, thereby minimizing the possibility of fraudulent financial reporting. Furthermore, creditors will consider various factors that influence the decision to apply for a loan. Of course, creditors will approve loan applications to companies that already have credibility, a good image, and are not sanctioned by the Financial Services Authority. Thus, these various factors cause companies not to manipulate financial statements even though they have financial risks in high leverage ratios.

Rationalization arises because individuals seek justification for their activities that contain fraud. Fraud perpetrators have the assumption that their behavior is ethical and reasonable because, so far, they have provided many services for the company. The accrual principle relates to the decision-making process by management and includes knowledge regarding rationalization in financial statements.

\section{Acknowledgment:}

This research funded the Basic Research Grants for Higher Education, DRPM DIKTI. Number: 22582/UN7.6.1/PP/2021

\section{References:}

[1] N. C. Situngkir and D. N. Triyanto, "Detecting Fraudulent Financial Reporting Using Fraud Score Model and Fraud Pentagon Theory: Empirical Study of Companies Listed in the L.Q. 45 Index," Indones. J. Account. Res., vol. 23, no. 03, pp. 373-410, 2020, DOI: 10.33312/ijar.486.

[2] Association of Certified Fraud Examiners (A.C.F.E.), "Report To the Nations 2018 
Global Study on Occupational Fraud and Abuse," 2018.

[3] S. S. Halbouni, N. Obeid, and A. Garbo, "Corporate governance and information technology in fraud prevention and detection: Evidence from the U.A.E.," Manag. Audit. J., vol. 31, no. 6-7, pp. 589628, 2016, DOI: 10.1108/MAJ-02-20151163.

[4] S. Wahyudi, T. Achmad, and I. D. Pamungkas, "Whistleblowing System and Fraud Early Warning System on Village Fund Fraud: The Indonesian Experience," Int. J. Financ. Res., vol. 10, no. 6, p. 211, 2019, doi: 10.5430/ijfr.v10n6p211.

[5] M. P. Sari, Kiswanto, L. V. Rahmadani, H. Khairunnisa, and I. D. Pamungkas, "Detection fraudulent financial reporting and corporate governance mechanisms using fraud diamond theory of the property and construction sectors in Indonesia," Humanit. Soc. Sci. Rev., vol. 8, no. 3, pp. 1065-1072, 2020, DOI: 10.18510/HSSR.2020.83109.

[6] C. Horwarth, "The Mind Behind The Fraudsters Crime: Key Behavioral and Environmental Element," Crowe Horwath L.L.P., pp. 1-62, 2012.

[7] S. A. Irwandi, I. Ghozali, Faisal, and I. D. Pamungkas, "Detection fraudulent financial statement: Beneish m-score model," W.S.E.A.S. Trans. Bus. Econ., vol. 16, no. May, pp. 271-281, 2019.

[8] I. D. Pamungkas, I. Ghozali, T. Achmad, M. Khaddafi, and R. Hidayah, "Corporate governance mechanisms in preventing accounting fraud: A study of fraud pentagon model," J. Appl. Econ. Sci., vol. 13, no. 2, 2018.

[9] Merdeka.com, "Fakta-fakta Kesalahan Laporan keuangan Garuda Indonesia Hingga Dikenakan Sanksi.," 2019.

[10] P. M. Dechow, R. G. Sloan, A. P. Sweeney, R. G. Sloan, and A. P. Sweeney, "Detecting Earnings Management," Asian Finance. Statement Anal., vol. 70, no. 2, pp. 73-105, 2015, DOI: 10.1002/9781119204763.ch4.

[11] C. J. Skousen and B. J. Twedt, "Fraud score analysis in emerging markets," Cross Cult. Manag. An Int. J., vol. 16, no. 3, pp. 301316, 2009.

[12] I. D. Pamungkas and S. D. Utomo, "Fraudulent Financial Reporting: An Application of Fraud Pentagon Theory to Association of Southeast Asian Nations Corporate Governance Scorecard," Journal of Advanced Research in Law and Economics 9 (5 (35)). pp. 1729-1737, 2018.

[13] S. Apriliana and L. Agustina, "The Analysis of Fraudulent Financial Reporting Determinant through Fraud Pentagon Approach," J. Din. Aunt., vol. 9, no. 2, pp. 154-165, 2017, DOI: 10.15294/jda.v7i1.4036.

[14] H. Daniel, A. Kamaluddin, Z. M. Sanusi, and K. S. Khairuddin, "Detecting Fraudulent Financial Reporting through Financial Statement Analysis," J. Adv. Manag. Sci., vol. 2, no. 1, pp. 17-22, 2014, DOI: 10.12720/joams.2.1.17-22.

[15] P. Husmawati, Y. Septriani, I. Rosita, and D. Handayani, "Fraud Pentagon Analysis in Assessing the Likelihood of Fraudulent Financial Statement (Study on Manufacturing Firms Listed in Bursa Efek Indonesia Period 2013-2016)," Int. Conf. Appl. Sci. Eng. Business, Linguist. Inf. Technol., no. October, pp. 45-51, 2017.

[16] E. Ratnasari and B. Solikhah, "Analisis Kecurangan Laporan Keuangan: Pendekatan Faud Pentagon Theory," Gorontalo Account. J., vol. 2, no. 2, pp. 98-112, 2019.

[17] E. Ratnasari and B. Solikhah, "Analisis Kecurangan Laporan Keuangan: Pendekatan Fraud Pentagon Theory," Gorontalo Account. J., vol. 2, no. 2, pp. 98-112, 2019.

[18] H. Yusrianti, I. Ghozali, and E. N. Yuyetta, "Asset misappropriation tendency: Rationalization, financial pressure, and the role of opportunity (study in Indonesian government sector)," Humanit. Soc. Sci. Rev., vol. 8, no. 1, pp. 373-382, 2020, DOI: 10.18510/hssr.2020.8148.

[19] I. D. Pamungkas, "A pilot study of corporate governance and accounting fraud: The fraud diamond model," J. Bus. Retail Manag. Res., vol. 12, no. 2, pp. 253-261, 2018, doi: 10.24052/jbrmr/v12is02/apsocgaaftfdm.

[20] R. D. Agustina and D. Pratomo, "Pengaruh Fraud Pentagon Dalam Mendeteksi Kecurangan Pelaporan Keuangan," J. Ilm. Manajemen, Ekon. Akunt., vol. 3, no. 1, pp. 44-62, 2019, doi: 10.31955/mea.vol3.iss1.pp44-62.

[21] I. M. L. Mertha Jaya and A. A. A. Poerwono, "Pengujian Teori Fraud Pentagon Terhadap Kecurangan Laporan Keuangan Pada Perusahaanpertambangan di Indonesia," Akuntabilitas J. Ilmu Akunt., vol. 12, no. 2, pp. 157-168, 2019, doi: 10.15408/akt.v12i2.12587. 
[22] G. L. Vousinas, "Advancing theory of fraud: the S.C.O.R.E. model," J. Financ. Crime, vol. 26, no. 1, pp. 372-381, 2019, doi: 10.1108/JFC-12-2017-0128.

[23] H. S. Rukmana, "Pentagon Fraud Affect on Financial Statement Fraud and Firm Value," South East Asia J. Contemp. Bus., vol. 16, no. 5, pp. 118-122, 2018.

[24] T. Achmada, I. Ghozali, I. D. Pamungkas, U. Diponegoro, and U. D. Nuswantoro, "Detection of Academic Dishonesty: A Perspective of the Fraud Pentagon Model," vol. 13, no. 12, 2020.

[25] D. Agustina, Ratna Dewi; Pratomo, "JIMEA | Jurnal Ilmiah MEA (Manajemen, Ekonomi, \& Akuntansi)," JIMEA | J. Ilm. MEA (Manajemen, Ekon. Akuntansi) 1,2Universitas, vol. 3, no. c, pp. 44-62, 2019, doi: 10.31955/mea.vol3.iss1.pp44-62.

[26] E. Evans, M. Metalia, E. Mirfazli, D. V. Georgieva, and I. Sastrodiharjo, "Business Ethics in Providing Financial Statements: The Testing of Fraud Pentagon Theory on the Manufacturing Sector in Indonesia," Bus. Ethics Leadersh., vol. 3, no. 3, pp. 68-77, 2019, DOI: 10.21272/bel.3(3).68-77.2019.

[27] S. D. Utomo and I. D. Pamungkas, "Cash flow activities and stock returns in manufacturing of Indonesia: A moderating role of earning management," Acad. Account. Finance. Stud. J., vol. 22, no. 6, pp. 1-10, 2018.

[28] W. Shi, B. L. Connelly, and R. E. Hoskisson, External corporate governance and financial fraud: cognitive evaluation theory insights on agency theory prescriptions, vol. 38, no. 6. 2017.

[29] I. Ghozali, T. Achmad, and I. D. Pamungkas, "Determinants of fraudulent financial reporting and whistleblowing system: Applying theory of planned behavior," W.S.E.A.S. Trans. Bus. Econ., vol. 16, 2019.

[30] H. S. Lastanti, "Role of Audit Committee in the Fraud Pentagon and Financial Statement Fraud," Int. J. Contemp. Account., vol. 2, no. $1, \quad$ p. $77, \quad 2020, \quad$ DOI: 10.25105/ijca.v2i1.7163.

[31] A. Yulianto, L. F. Dahriyanto, R. Wijayanti, and P. Adininggar, "The Effect of Fraud Pentagon and Academic Procrastination Dimensions Towards Academic Dishonesty of Students of Social Science in Senior High School of Semarang," vol. 464, no. Psshers 2019, pp. 1158-1169, 2020, doi: 10.2991/assehr.k.200824.251.
[32] S. tri Nanda, N. Salmiah, and D. Mulyana, "Fraudulent Financial Reporting: a Pentagon Fraud Analysis," J. Ilm. Ekon. Dan Bisnis, vol. 16, no. 2, pp. 122-134, 2019, doi: 10.31849/jieb.v16i2.2678.

[33] D. N. Rahmatika, M. D. Kartikasari, D. Dewi Indriasih, I. A. Sari, and A. Mulia, "Detection of Fraudulent Financial Statement; Can Perspective of Fraud Diamond Theory be applied to Property, Real Estate, and Building Construction Companies in Indonesia?," Eur. J. Bus. Manag. Res., vol. 4, no. 6, pp. 1-9, 2019, doi: 10.24018/ejbmr.2019.4.6.139.

[34] L. P. Widianingsih, "Students Cheating Behaviors: The Influence of Fraud Triangle," Integr. Bus. Econ. Res., vol. 2, no. 2, pp. 252-260, 2013.

[35] E. Y. Ibrani, F. Faisal, and Y. D. Handayani, "Determinant of non-GAAP earnings management practices and its impact on firm value," Cogent Bus. Manag., vol. 6, no. 1, pp. $\quad 1-17, \quad 2019, \quad$ DOI: 10.1080/23311975.2019.1666642.

[36] M. P. Sari, N. Pramasheilla, F. -, T. Suryarini, and I. D. Pamungkas, "Analysis of Fraudulent Financial Reporting With the Role of K.A.P. Big Four as a Moderation Variable: Crowe's Fraud's Pentagon Theory," Int. J. Financ. Res., vol. 11, no. 5, p. 180, 2020, DOI: 10.5430/ijfr.v11n5p180.

[37] D. T. Wolfe and D. R. Hermanson, "The fraud diamond: Considering the four elements of fraud," 2004.

[38] T. Achmad and I. D. Pamungkas, "Fraudulent Financial Reporting Based of Fraud Diamond Theory: A Study of the Banking Sector in Indonesia," J.I.A.F.E. (Jurnal Ilm. Aunt. Fak. Ekon., vol. 4, no. 2, pp. 135-150, 2018.

[39] N. D. A. Nugraha and D. Henny, "Pendeteksian Laporan Keuangan Melalui Faktor Resiko, Tekanan dan Peluang," $e$ Journal Akunt. Trisakti, vol. 2, no. 1, pp. 2948, 2015.

[40] Jullani, Mukhzarudfa, and Yudi, "Deteksi Fraudulent Financial Reporting dengan Menggunakan Perspektif Teori Fraud Pentagon," J. Akunt. dan Keuang. Univ. Jambi, vol. 5, no. 3, pp. 158-168, 2020.

[41] C. Tessa and P. Harto, "Fraudulent Financial Reporting: Pengujian Teori Fraud Pentagon Pada Sektor Keuangan Perbankan di Indonesia," Simp. Nas. Akunt. XIX Lampung, vol. 19, pp. 1-21, 2016. 
[42] A. L. Hardika, D. T. H. Manurung, and Y. Mulyati, "Corporate Governance Mechanism, Company Size Financial Performance and Sustainability Reporting," Int. J. Eng. Technol., vol. 7, no. 4.34, pp. 201-203, 2018.

[43] Y.-I. Lou and M.-L. Wang, "Fraud Risk Factor Of The Fraud Triangle Assessing The Likelihood Of Fraudulent Financial Reporting," J. Bus. Econ. Res., vol. 7, no. 2, pp. 61-78, 2011, doi: 10.19030/jber.v7i2.2262.

[44] T. Achmad and I. D. Pamungkas, "Fraudulent Financial Reporting Based Of Fraud Diamond Theory," J.I.A.F.E. (Jurnal Ilm. Aunt. ..., 2019, [Online]. Available: https://journal.unpak.ac.id/index.php/jiafe/art icle/view/1112.

[45] I. G. N. H. Sawaka K., "Fraud pentagon theory in detecting financial perception of financial reporting with good corporate governance as moderator variable," Int. Res. J. Manag. I.T. Soc. Sci., vol. 7, no. 1, pp. 8494, 2020, doi: 10.21744/irjmis.v7n1.824.

[46] D. N. Triyanto, "Fraudulence Financial Statements Analysis using Pentagon Fraud Approach," J. Account. Audit. Bus., vol. 2, no. 2, p. 26, 2019, DOI: 10.24198/jaab.v2i2.22641.
Contribution of Individual Authors to the Creation of a Scientific Article (Ghostwriting Policy)

\section{Ahmad, Tarmizi}

Formulation idea; objectives and benefits of research. Design of theoretical framework and sampling technique.

\section{Hapsari, Dian Indriana}

Methodology development or design; data tabulation, data processing, and result

\section{Pamungkas, Imang Dapit}

Analyze and conclude as well as create tables, figures, adjust journal templates, revision and as a correspondent Author

\section{Creative Commons Attribution License 4.0 \\ (Attribution 4.0 International, CC BY 4.0)}

This article is published under the terms of the Creative Commons Attribution License 4.0 https://creativecommons.org/licenses/by/4.0/deed.en US 